Ryczkowski M., Is deflation trap a serious threat? Case study of FED, ECB and NBP, „Ekonomia i Prawo. Economics and Law”, Polszakiewicz B., Boehlke J. (ed.), Vol. 14, No. 2/2015, pp. 243259. DOI: http://dx.doi.org/10.12775/EiP.2015.015.

\author{
MACIEJ RYCZKOWSKI*
}

\title{
IS DEFLATION TRAP A SERIOUS THREAT? CASE STUDY OF FED, ECB AND NBP
}

\author{
SUMMARY
}

The goal of the paper is to compare nonstandard solutions implemented by Federal Reserve System, European Central Bank and National Bank of Poland in response to the outbreak of a subrime crisis in United States and to debt crisis in European Union. For that purpose there is carried out a comparative, descriptive analysis of institutional steps taken by the three central banks and the governments to preserve macroeconomic stability. The nonstandard measures allowed to avoid a comeback of the Great Depression and restored market's confidence, unfortunately at the cost of decreased resilience for future possible crises along with many other medium and long run unintended consequences.

Keywords: nonstandard monetary policy measures, deflation trap, liquidity trap JEL Classification: E31, E32, E58

\section{INTRODUCTION}

Deflation is perceived generally as undesirable or even dangerous phenomena. Short term fall of prices in the economy or periodical price decreas-

" Maciej Ryczkowski, Nicolaus Copernicus University, Faculty of Economic Sciences and Management, Department of Economics, ul. Gagarina 13A, 87-100 Toruń, Poland, phone: +48 603532 394, e-mail: maciej.ryczkowski@wp.pl. 
es in particular sectors of the economy are quite common. They result from higher global or local competitiveness, changing customer preferences, positive supply shocks caused by productivity increases, new technologies or external factors among which could be listed lower prices of imported production factors. In such circumstances deflation is not particularly dangerous. On the contrary, mentioned causes of deflation increase output, which might offset negative impact of deflation. A real danger for the economy arises when deflation gets continuous and is accompanied or created by contractionary demand shock. Negative impact of deflation on a weakened economy can lead to downward spiral of prices, that may lead to a persistent deflation self-reinforcing by anchored deflationary expectations.

Contractionary deflation might harm economic activity. When economy is subjected to nominal wage rigidities it increases unemployment, deflation dampens credit activity as real interest rates rise, it increases the real debt burden of debt holders (so called: debt deflation ${ }^{1}$ ) — which might further lead to deterioration of their balance sheets resulting consecutively in moral hazard and adverse selection problems, economic agents are discouraged from investing as real value of money rises, the alternative cost of investments increases, deflation arbitrary redistributes the wealth from borrowers to lenders, decreases government's revenues, creates menu costs and might be malign for monetary policy. The experience of persistent deflation is scarce making it difficult to estimate real costs of continuous deflation. Nevertheless, existing experiences confirm that contractious, persistent deflation is damaging for the economy and that it is not easy to cure. The case study of Japan is a warning that getting the economy out of the deflation trap might be a difficult challenge ${ }^{2}$. Unfavorable Japanese experiences and recognized channels of destructive deflation's impact contributed to formulating the dominant point of view, that deflation is harmful for the economy. Persistent deflation seems to be not only harmful but its probability of occurrence was till recently highly underestimated. After the 2007-2009 crisis, many monetary authorities recognized that the risk of falling into deflation is considerably greater than it was believed ${ }^{3}$. Therefore, it seems reasonable to treat the inflation target symmetrically.

${ }^{1}$ I. Fisher, The Debt-Deflation Theory of Great Depressions, „Econometrica”, Vol. 1, No. 4/1933, pp. 337-357.

${ }^{2}$ H. Kuroda, Overcoming Deflation: The Bank of Japan's Challenge, Speech at the Council on Foreign Relations in New York, 2013.

${ }^{3}$ M. Kumar, T. Baig, J. Decressin, C. Faulkner-MacDonagh, T. Feyzioglu, Deflation: Determinants, Risks, and Policy Options, IMF Occasional Paper, No. 221/2003; J.H.E. Christensen, J.A. Lopez, G.D. Rudebusch, Extracting Deflation Probability Forecasts from Treasury Yields, „International Journal of Central Banking”, Vol. 8 No. 4/2012, pp. 21-60. 


\section{THE CURRENT STATE OF KNOWLEDGE}

The institutional monetary policy frameworks, that turned out to be effective at both disinflation and maintaining low inflation environment with low variance of inflation are the implicite or explicite inflation targeting versions, introduced first by New Zealand (explicite one) in the year 1990. Poland implemented explicite version eight years later too. Since the beginning of 2004, the continuous inflation target was set at $2.5 \%$ with a permissible fluctuation band of +/- 1 p.p. European Central Bank selected the inflation target in a more blurry way stating that it aims at inflation rates of below, but close to, $2.0 \%$ over the medium term. Federal Reserve System exercises the implicite kind of this framework with no officially appointed inflation target. Implicite or explicite inflation targeting is an embodiment of Rogoff's proposal of a conservative central banker, that assigns to combating inflation high but limited weight ${ }^{4}$. Inflation targeting framework is a solution to time-inconsistency trap, because it puts on monetary authorities certain cost when inflation exceeds target ranges ${ }^{5}$. Aoki presents modifications of basic inflation targeting framework to make it more prone to deflation ${ }^{6}$. However, the framework itself (with its standard instruments: interest rates, standard open market operations, reserve requirements) might be not enough to anchor higher inflation expectations when sufficiently severe contractionary demand shock appears.

Therefore, Summers (1991) warned that deflation might be especially troublesome for monetary authorities as the usage of nominal interest rates is limited by zero lower bound (ZLB), which might cause monetary policy incapable to effectively influence prices. It means a danger of falling into the liquidity trap as it happened in the Japanese case. Undoubtedly, nominal interest rates are important and basic instrument of monetary authorities. National Bank of Poland openly underlines that they are the main instrument of achieving the desired inflation:"National Bank of Poland influences the level of inflation mainly by determining the official interest rates, which define yields on monetary policy instruments" - as it is stated at NBP's web page. While this statement seems appropriate for inflation periods, it is less correct when deflation forces monetary authorities to lower official interests rates to

${ }^{4}$ K. Rogoff, The Optimal Degree of Commitment to an Intermediate Monetary Target, „Quarterly Journal of Economics", Vol. 100, No. 4/1985.

${ }^{5}$ F.S. Mishkin, N.J. Westelius, Inflation Band Targeting and Optimal Inflation Contracts, "Journal of Money, Credit and Banking", Vol. 40, No. 4/2008.

${ }^{6}$ M. Aoki, A Desirable Inflation Targeting Policy in a Deflationary Economy: The Case of Japan, The Japan Research Institute Working Paper, http://papers. ssrn.com/sol3/papers. cfm?abstract_ $\mathrm{id}=1868633$ (21.02.2015). 
miniscule levels. European Central Bank, operating in an environment where the crisis was more severe and thus deflation risk was higher, is more cautious with determining the relative importance of each instruments and only generally states that:"to achieve its primary objective, the Eurosystem uses a set of monetary policy instruments and procedures." Despite the fact, that interest rates are important instrument, literature and recent monetary policy responses to the contractionary shock after the year 2007 indicate that monetary authorities while in ZLB still can take steps and means to try to escape from the liquidity and deflation trap ${ }^{7}$. Nonstandard measures, that are suggested to overcome the deflation include: forward guidance, qualitative easing, quantitative easing, transfers of money to the public sector, money printing, nominal GDP targeting, price level targeting, setting higher inflation target for an extended time period, depreciation of the exchange rate, cash taxation, carry tax, negative interest rates on bank reserves and some degree of cooperation between monetary and fiscal policies.

Nevertheless, implementing most of the mentioned above solutions requires institutional changes in fully-fledged inflation targeting countries, like Poland. Undoubtedly, boosting the economy by purchasing government securities or private junk bonds, printing money and depreciating the exchange rate, or changing the targeting scheme to price level targeting would be a considerable institutional change. In Poland it would be even necessary to change a constitution to allow the central bank to purchase government bonds. Currently paragraph 220 of Polish constitution states that Budget Act cannot assume that the budget deficit will be financed by the central bank (Para. 220, Chapter X) ${ }^{8}$. Purchasing junk bonds or depreciation of the exchange rate $^{9}$ in polish circumstances could be viewed by the public as decreased will to combat inflation and could result in lost credibility of NBP. Institutional changes of that kind are already not required in FED and ECB as they, first of all, do not meet the criteria of fully-fledged inflation target-

${ }^{7}$ Liquidity trap and deflation trap are not the same, although they are interconnected to each other and for the purpose of this paper they are investigated as they were the same, because in terms of contractionary demand shock the same solutions to get the economy out of the liquidity trap can be suggested to get the economy out of the deflation trap.

${ }^{8}$ Case of Poland is atypical. Banking sector in Poland is over-liquid. Bank reserves are so huge, that it is the central bank that is forced to borrow money from commercial banks. It might be therefore a very deep, severe contraction that purchases of commercial banks' bonds would be necessary, more possibly on the micro-scale to perform the lender of the last resort function to recapitalize a given bank facing a bankruptcy (Konstytucja Rzeczypospolitej Polskiej z dnia 2 kwietnia 1997 r. (Constitution of April 2, 1997), Dz.U., No. 78, item 483.).

${ }^{9}$ Not to mention worsened situation of debtors, whose debt is denominated in foreign currency. 
ing strategy (especially FED) and, besides that, they already changed their institutional approach, as both FED and ECB had the mandate and the will to broaden their standard tools, to implement non-standard solutions to defend against drying off lending at the interbank market resulting from contractionary demand shock after 2007. The greatest change of all three central banks happened when ECB took a decision to purchase sovereign bonds of the PIIGS countries ${ }^{10}$ after the outbreak of a debt crisis in the Euro area, despite protests of some German societies and contrary to conventional tradition of the BundesBank.

\section{THE METHDOLOGY OF RESEARCH}

Quarterly and annual data come from Federal Reserve System, European Central Bank data Warehouse, National Bank of Poland, Eurostat and Central Statistical Office of Poland and span from the year 2006 or 2007 (depending on the particular time series) to 2014. For the purpose of analyzing the liquidity trap problem, the paper presents the case study of three central banks FED, ECB and NBP. The qualitative description of the monetary policy stance and instruments implemented by the three central banks are supported by simple quantitative analysis, namely the economic results of the three central banks are compared with the costs needed to achieve mentioned results. In particular, pre and post crisis economic outcomes, like CPI inflation, real GDP growth and unemployment rate are compared with the consequences of the implemented measures: central banks' total assets, public debt to GDP ratios and official policy rates.

\section{THE RESEARCH PROCESS: FED, ECB AND NBP - SOLUTIONS IMPLEMENTED}

Zero lower bound is not just a theoretical possibility that accidentally happened to Japan. After the sub-prime crisis struck, FED immediately lowered its federal funds rate virtually to zero. ECB was more conservative and hesitated with lowering the rate of main refinancing operations till economic turbulences became evident in Europe. Its approach was gradual, indicating underestimation of the crisis severity. Out of the three banks, only NBP has still two p.p. of relative safety to ZLB at the end of 2014.

\footnotetext{
${ }^{10}$ Portugal, Italy, Ireland, Greece, Spain.
} 


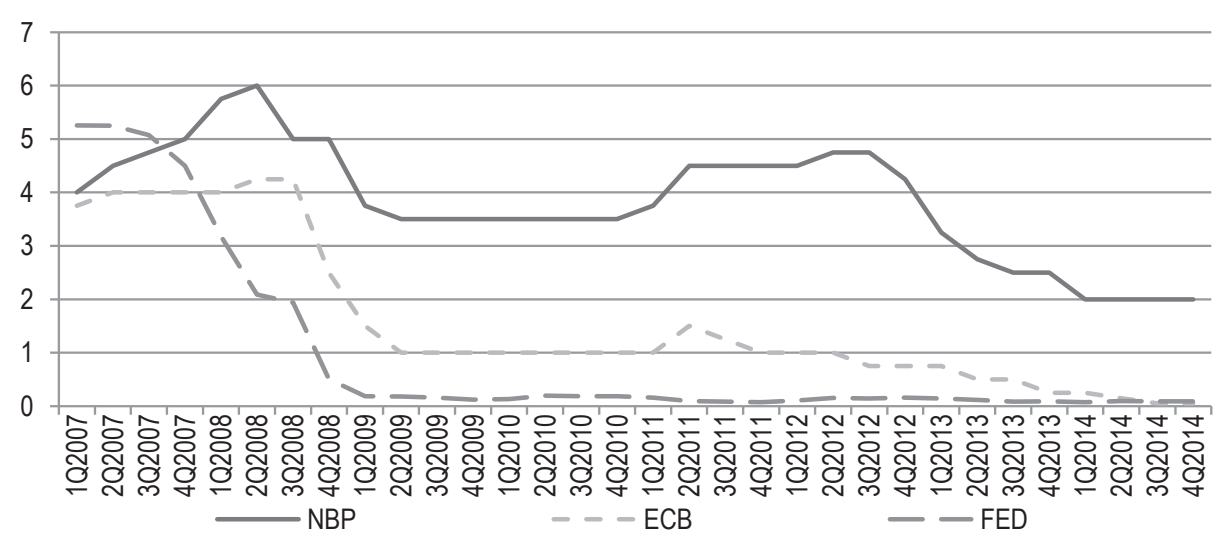

Figure 1. Official policy rates of FED, ECB and NBP in period 2007-2014 (in \%) Federal funds rate, main ECB refinancing operations rate, NBP's reference rate

Source: Own preparation based on FED, ECB, NBP.

When nominal rates lowering was no longer a possibility to stimulate inflation and economy in USA and in euro area, this standard instrument had to be supported by forward guidance. The Governing Council of ECB implemented forward guidance by announcing a commitment that the key ECB interest rates would remain at present or lower levels for an extended period of time. The term "extended period of time" was however not specified making the forward guidance less reliable, which is a serious flaw as credibility is crucial for effectiveness of this tool.

FED implemented more exact forward guidance by determining 0 to $1 / 4$ percent target range for the federal funds rate following the end of its asset purchase program in October 2014. Moreover, the bank specified the time frames by announcing that forward guidance will last if projected inflation continues to be below the Committee's 2 percent long-run goal, and provided that long-term inflation expectations remain well anchored.

NBP's forward guidance is aimed not on anchoring long-run inflation expectations, but on shorter periods of time. While ECB and FED used it as a tool to overcome ZLB, NBP uses it only to anchor few months expectations at stable levels, which would certainly be not enough to inflate in case of persistent deflation accompanied by ZLB. At the conference in July 2013 president of NBP announced that interest rates would probably remain unchanged till the end of 2013. In November 2013 it was declared that interest rates would remain probably unchanged till the end of June 2014, but this period was in March 2014 extended till the end of third quarter of 2014. NBP, similarly like ECB, does not declare conditions of exiting forward guidance, which might increase uncertainty and decrease efficiency of this tool. 
Table 1. Nonstandard solutions implemented by ECB, FED and NBP after 2007 in response to the crisis

\begin{tabular}{|c|c|c|c|}
\hline INSTRUMENT & ECB & FED & NBP \\
\hline ZLB on policy rates & Yes & Yes & No \\
\hline Forward guidance (FG) & Yes & Yes & Yes \\
\hline FG near ZLB & Yes & Yes & No \\
\hline Long-run FG & Yes & Yes & No \\
\hline FG exit strategy & No & Yes & No \\
\hline Qualitative easing & Yes & Yes & Yes \\
\hline Quantitative easing & Yes & Yes & Yes \\
\hline Price level targeting & No & No & No \\
\hline Higher inflation target & No & No & No \\
\hline Exchange rate depreciation & No & No & No \\
\hline Negative interest rates & Yes & No & No \\
\hline Fiscal stimulus & Yes & Yes & No \\
\hline
\end{tabular}

Source: Own preparation.

Among the most important measures, implemented after the outbreak of the crisis, were qualitative/quantitative easing policies. ECB supported regular operations by implementation of two liquidity-providing longterm refinancing operations in euro with a three-year maturity (maturing on 29 January 2015 and on 26 February 2015), as well as of US dollar. In June 2014, ECB announced that it will conduct a series of targeted longerterm refinancing operations (TLTROs), which goal is to improve bank lending to the euro area non-financial private sector over a period of two years, however excluding loans to households for house purchase.

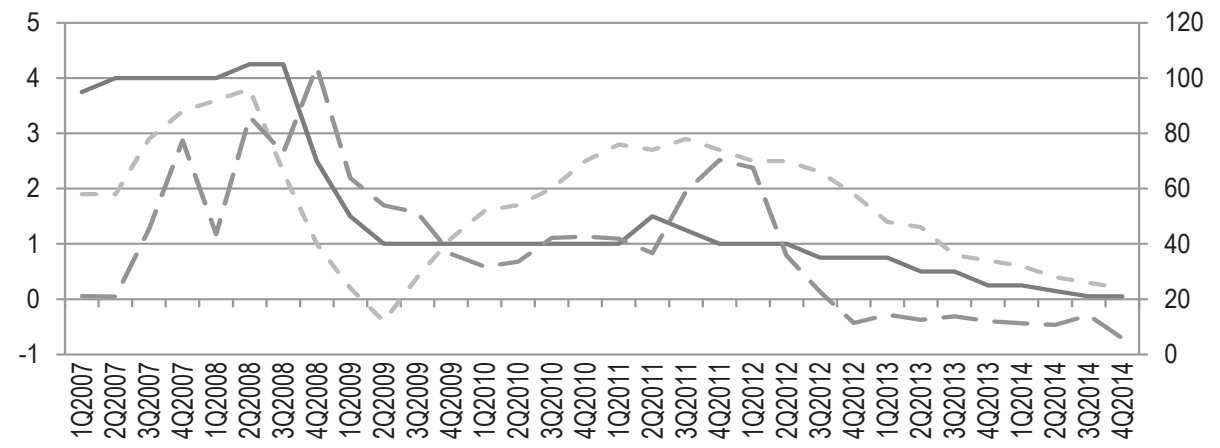

main refinancing operations rate (left scale) $\quad---\mathrm{CPI}$ inflation (left scale)

Figure 2. Euro Area: policy rates, inflation (in \%) and restoration of market's confidence measured by EURIBOR3M-EONIA spread (in b.p.) in period 2007-2014

Source: Own preparation based on ECB and EUROSTAT. 
Moreover, earlier in 2009 and in 2011 two covered bond purchase programmes were introduced (the CBPP — ended in June 2010, CBPP2 - ended in October 2012). ECB from 10th of May 2010 to February 2012 launched the Securities Markets Programme (SMP) in order to conduct interventions in debt markets. The programme was finally terminated in September 2012. However, in August 2012 the ECB announced the unprecedented possibility of conducting outright open market operations in secondary sovereign bond markets. In September 2014, ECB announced two new purchase programmes: the ABS purchase programme (ABSPP) and the third covered bond purchase programme (CBPP3). The purchases are carried out both in primary and secondary markets. It seems that it may be not over of expansionary nonconventional policies. The European Central Bank's Governing Council along with President Draghi expect to consider a new package of broad-based asset purchases, which would include sovereign debt in 2015.

FED was extremely expansionary after the outbreak of the crisis. Federal Reserve made a series of large-scale asset purchases (LSAPs), between late 2008 and October 2014. The bank purchased long-term securities issued by the U.S. government in the private market through a competitive process and long-term securities issued or guaranteed by government-sponsored agencies such as Fannie Mae or Freddie Mac. Although Fed did not purchase government securities directly from the U.S. Treasury, the size of the intervention was amazing.



Figure 3. United States: policy rates, inflation (in \%) and restoration of market's confidence measured by TED spread (in b.p.) in period 2007-2014

Source: Own preparation based on FED.

When the space for ongoing cuts of the federal funds rate became limited, FED launched its first large-scale purchases dubbed quantitative eas- 
ing number 1, abbreviated as QE1. Altogether later it turned out that QE1 was not enough and QE2 as well as QE3 were introduced too. In November 2008 Federal Open Market Committee (FOMC) initiated first huge expansionary purchases, which amounted to a total of 600 billion USD in agency mortgage-backed securities and agency debt (see Board of Governors, 2008). The purchase programme was considerably expanded. In March 2009 FOMC announced that up to 1.25 trillion USD of agency mortgage backed securities, up to 200 billion USD of agency debt and up to 300 billion USD of longterm treasury debt will be purchased (see Board of Governors, 2009). In early 2010 the purchases were completed finishing first period of extraordinarily expansionary policy. Second round of large scale purchases dubbed QE2 started in November 2010. At that time FOMC stated it would continue purchases of security holdings. Over a period ending in mid-2011 long-term Treasury securities to the amount of additional 600 billion USD were purchased (see Board of Governors, 2010). Later in 2011 FOMC introduced maturity extension program (MEP), which was a variation of earlier solutions. In line with MEP central bank purchased 400 billion USD of long-term Treasury securities and sold an equivalent amount of shorter-term Treasury securities over the period ending in June 2012 (see Board of Governors press release (2011). Nevertheless, FOMC extended the program till the end of 2012.

Finally, QE3 was launched the same year, that is in October 2012. The Committee continued purchases of mortgage-backed securities at a pace of 40 billion USD a month. FOMC decided also to implement qualitative easing policies by extending the average maturity of its Treasury securities' holdings. Committee decided to maintain ongoing reinvestments of its principal holdings of agency debt and agency mortgage backed securities again into agency mortgage backed securities. These actions were believed to decrease long-term interest rates, support mortgage markets, improve broader financial conditions. In October 2014 Fed ended its historic bond-buying program, a massive effort to stimulate the economy known as QE3.

Situation in Poland was strikingly different from that in United States and in Euro Area. Polish banking sector since half of the 90. is characterized by over-liquidity. That made it more crisis-proof and resistant to cognition effects. Although the whole banking system was stable, some banks experienced problems with managing their liquidity. A lack of trust, represented by peaking spread between POLONIA and WIBOR rates, appeared at the interbank market. NBP took successfully standard and nonstandard steps to restore the necessary confidence (figure 4). 


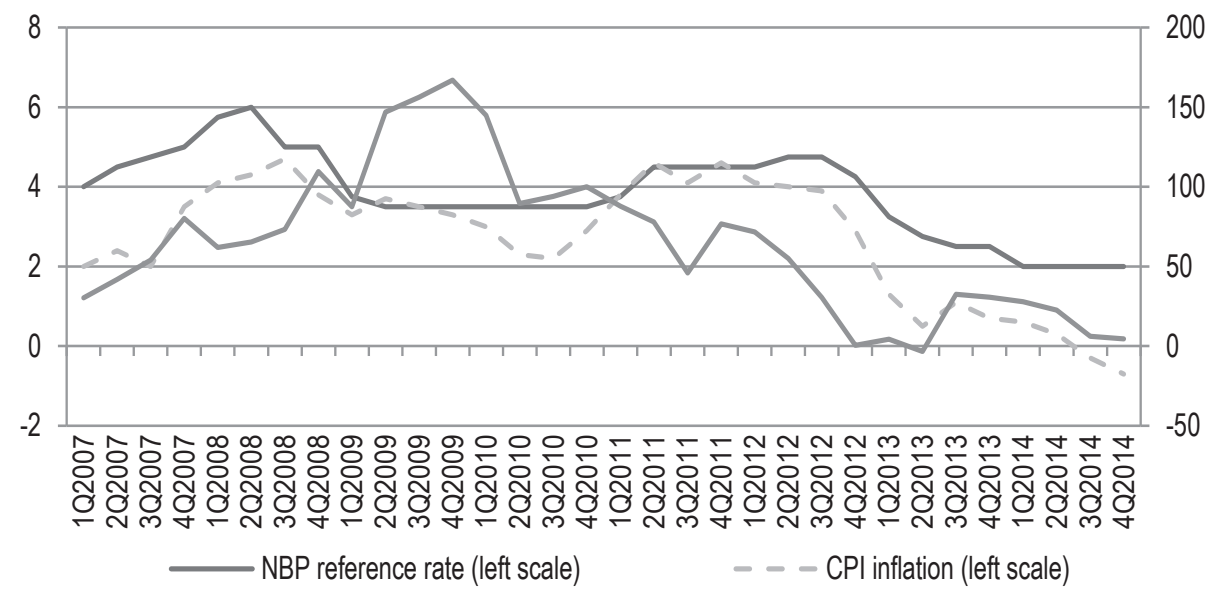

Figure 4. Poland: policy rates, inflation (in \%) and restoration of market's confidence measured by WIBOR3M-POLONIA spread (in b.p.) in period 2007-2014

Source: Own preparation based on NBP and GUS.

One of the most important actions, which was introduced to avoid a credit crunch, took place on 14th of October 2008. President of NBP announced a spectrum of actions that the bank decided to carry out along with a special program called The Packet of Trust (Pakiet Zaufania). The bank launched liquidity providing operations with three month maturity, increased the frequency of open market operations, announced maintenance of issuing 7-day NBP Bills as a main instrument of liquidity sterilization, introduced SWAP operations, modified lombard credit arrangements: decreased haircut, broadened the list of collateral securities. Later, next modifications were introduced, including increasing maturity of the open market operations and further broadening the list of securities accepted as collateral.

Despite convincing reasons that low interests rates might be harmful for the economy ${ }^{11}$ and despite the fact, that negative deposit rates not necessarily stimulate spending ${ }^{12}$, ECB decided to lower its deposit rates below zero. ECB implemented negative deposit facility of $-0.1 \%$ on 11th of June 2014 to decrease it further to $-0.2 \%$ since 10 th September the same year. FED did not decide to exercise negative deposit rates, however its deposit rates virtually equal zero. On January 13, 2014, the Federal Reserve conducted a fixedrate offering of term deposits with full allotment of tenders through its Term

${ }^{11}$ A. Rzońca, Kryzys Banków Centralnych - skutki stopy procentowej bliskiej zera, C.H. Beck, Warszawa 2014.

${ }_{12} \mathrm{R}$. Rajan, A step in the dark: unconventional monetary policy after the crisis, Andrew Crockett Memorial Lecture by Raghuram Rajan, 2013. 
Deposit Facility. The operation offered 28-day term deposits at an interest rate of 0.26 percent. In December 2014 the operation offered seven-day term deposits at an interest rate of 0.30 percent. NBP at the end of 2014 was still relatively far from negative deposit rates. Since July 2013 the deposit rate is low but positive and amounts to $1.0 \%$.

Assessing the impact of monetary policy on the recovery and on escaping from deflation trap should not be carried out regardless of fiscal policy. American Congress on 13th of February 2009 passed the American Recovery and Reinvestment Act. The act was commonly referred to as the "stimulus package". Its volume amounted originally to 787 billion USD. However, in 2011 it was increased to 840 billion USD to be in line with the budget for 2012 .

At the end of 2008, there was also announced The European Economic Recovery Plan. The plan consisted of two pillars. First pillar was to boost aggregated demand and to restore confidence by injection of money into the economy. The European Comission proposed that Member States and the European Union decided to give an immediate budgetary impulse amounting to $€ 200$ billion, which represented $1.5 \%$ of UE GDP. The second pillar outlined the need to reinforce Europe's competitiveness in the long term and gave a number of proposals: creating low-carbon economy, smart investments, appropriate labor market policies, investing in energy efficiency, clean technologies, infrastructure and inter-connection, opening up new finance for SMEs and cutting administrative burdens.

In case of Poland, there was generally little room for fiscal stimulus. In 2013 the debt to GDP ratio was 58.3\% and budget deficit was high (-4.3\%). Poland's debt to GDP ratio is very close to the threshold set in article 216 of the constitution ${ }^{13}$. In line with the article, it is not allowed to lend, to give guarantees and sponsorships when the debt exceeds three fifths of the annual GDP. Nevertheless, thresholds might be arbitrary changed. In 2013 government suspended the implications imposed by first threshold. The implications were to be introduced, when the debt to GDP ratio would amount to between 50 and 55.0\%. Along with them, the planned deficit for the next year would not be allowed to exceed the current value of a budget deficit.

Other institutional solutions, that could help to overcome the deflation trap, i.e. price level targeting, setting higher inflation target and depreciation of the exchange rate were not implemented neither by ECB, FED nor NBP. The reason for that might be that price level targeting and a commitment to target higher inflation seem to have little impact on creating higher inflation

${ }^{13}$ Konstytucja Rzeczypospolitej Polskiej z dnia 2 kwietnia 1997 r..., op. cit. 
expectations when the contractionary demand shock is of considerable size. Moreover, all three measures have serious drawbacks, possibly highly damaging for the economy.

\section{THE RESULTS OF THE RESEARCH}

The goals of nonstandard monetary policy measures implemented after the outbreak of a crisis 2007-2009 were to not to allow a Great Depression happen ever again, to preserve macroeconomic stability, to restore market's confidence and to escape from a possibility of falling into deflation trap. When the use of expansionary fiscal policy was limited due to big debts, monetary policy by 'becoming the only game in town' was made responsible to a large extent for output stabilization.

The analysis of this chapter allows to compare the pre crisis and post crisis variables. The pre crisis year is the year 2006. While for the post crisis year was selected the year 2014, to try to catch the longest available data to assess the current impact of the measures implemented. Obviously, such a simple comparison does not take into account casuality, different initial conditions of particular central banks or external factors affecting the outcomes. Therefore, it cannot be treated as an evaluation of the efficiency of the nonstandard measures implemented. The analysis might be instead treated as an evaluation whether a given central bank (together with government or despite it) managed to obtain particular outcomes taking into account the environment it is operating within.

Despite the fact, that in existing literature one can find no agreement on the efficiency of the nonstandard measures, undoubtedly without those measures the magnitudes of the contraction would be much bigger ${ }^{14}$. The nonstandard measures allowed to avoid a comeback of the Great Depression (table 2).

Seven years after the outbreak of a crisis, the unemployment rate deteriorated in USA and in Euro Area. Output growth deteriorated in all three countries. Nevertheless, despite the output growth is not big in comparison to pre crisis values (with USA as an exception), the contraction did not cause falls noted during the Great Depression. Similarly the unemployment

${ }^{14}$ M. Bech, L. Gambacorta, E. Kharroubi, Monetary policy in a downturn: Are financial crises special?, BIS Working Papers, No. 388/2012; H. Chen, V. Curdia, A. Ferrero, The Macroeconomic Effects Of Large-Scale Asset Purchase Programmes, „The Economic Journal”, Vol. 122, No. 564/2012, pp. F289-F315. 
rates, despite higher (with an exception of Poland), are far from the situation, when one on four US citizens was unemployed, like in the 30s. The inflation is still low, sending warning signals about potential deflation. The nonstandard measures did not manage to anchor high inflation expectations, regardless of the external factors in Euro Area nor in Poland. Highly expansionary policies allowed however to inflate in the United States.

Table 2. Basic pre (year 2006) and post crisis (year 2014) economic variables (in \%)

\begin{tabular}{|c|c|c|c|c|c|c|}
\hline SPECYFICATION & \multicolumn{2}{|c|}{ USA } & \multicolumn{2}{c|}{ EURO AREA } & \multicolumn{2}{c|}{ POLAND } \\
\hline Evaluation/year & 2006 & 2014 & 2006 & 2014 & 2006 & 2014 \\
\hline Unemployment rate & 4.60 & 6.20 & 8.30 & 11.6 & 13.8 & 9.0 \\
\hline GDP growth rate & 2.7 & 2.4 & 3.40 & $-0.5^{*}$ & 6.2 & 3.3 \\
\hline CPI inflation & 3.2 & 1.6 & 2.2 & 0.4 & 1.3 & 0.1 \\
\hline
\end{tabular}

Source: Own preparation based on OECD, EUROSTAT, GUS



Figure 5. FED and ECB's total assets in period 2006-2015, not seasonally adjusted (in mln USD) Source: Own preparation based on FED.

All three banks had to face a problem of rising uncertainty that appeared on the market. Figures 1, 2, 3 show that FED, ECB as well as NBP managed to restore market's confidence. The TED, EURIBOR3M-EONIA and WIBOR3M-POLONIA spreads decreased to its pre crisis values. Obtained results are in line with other researchers' outcomes. For example, Hancock and Passmore $^{15}$ claim that intervention of Fed markedly improved market conditions, while ECB successfully avoided consequences similar to those during

15 D. Hancock, W. Passmore, Did the Federal Reserve's MBS Purchase Program Lower Mortgage Rates?, „Journal of Monetary Economics”, Vol. 58, No. 5/2011, pp. 498-514. 
the Great Depression of the $30 \mathrm{~s}^{16}$, the bank still fails to achieve its price stability objective ${ }^{17}$.

The successes of nonstandard measures, mentioned above: avoidance of a severe depression and restoration of market confidence, were not a 'free lunch'. Most apparent costs include an increase of the relation of public debt to GDP and an enormous increase of central banks' total assets, especially in case of FED (figure 5). In Poland both, the rise of public debt in relation to GDP as well as a rise of NBP's total assets were moderate (table 3).

Table 3. Public debt in terms of GDP and central bank's total assets - comparison of pre-crisis values (year 2006) and post crisis values (year 2014) for United States, Euro Area and Poland

\begin{tabular}{|c|c|c|c|c|c|c|}
\hline SPECYFICATION & \multicolumn{2}{|c|}{ USA } & \multicolumn{2}{c|}{ EURO AREA } & \multicolumn{2}{c|}{ POLAND } \\
\hline Costs/year & 2006 & 2014 & 2006 & 2014 & 2006 & 2014 \\
\hline Public debt/GDP (in \%) & 63.3 & 101.5 & 66.6 & 92.0 & 47.1 & 58.0 \\
\hline Central bank's total assets & 869988 & 4497660 & 1150030 & 2150247 & 155078 & 321255 \\
\hline
\end{tabular}

Source: Own preparation based on FED, ECB, NBP, GUS, EUROSTAT.

The question about the long or medium term implications of such policies remains open. In literature there are recognized many possible, negative consequences of the implemented measures ${ }^{18}$. Regardless of those wide lists of possible, severe consequences, one thing is sure, already stretched fiscal debts and greatly expanded central banks' balance sheets create an environment extremely vulnerable to severe crisis. In case new, considerably huge contractionary shock hit again USA or Euro Area, then both fiscal and monetary policies would not be able to remain as expansionary as they were after the 2007-2009 crisis. Moreover, improvement of central banks' balance sheets and confronting sovereign debt problems are processes, that need much time. As the economy keeps on continuing a recovery process, a probability of a new crisis would gradually increase, which altogether with the imbalances in fiscal and monetary policies may prepare grounds for future severe depression. To avoid it, some rules, frameworks or exit strategies from easy monetary policy and from governments' fiscal packages are necessary.

16 D. Giannone, M. Lenza, H. Pill, L. Reichlin, Non-Standard Monetary Policy Measures and Monetary Developments, ECB Working Paper, No 1290/2011.

17 Á. Ubide, Is the European Central Bank Failing Its Price Stability Mandate?, „Policy Brief”, Peterson Institute for International Economics, No. PB14-5/2014.

18 A. Rzońca, op. cit.; W.R. White, Ultra easy monetary policy and the law of unintended consequences, „Real-world Economics Review”, No. 63/2013; R. Rajan, op. cit. 


\section{CONCLUSIONS}

In response to severe contractionary shocks, FED, ECB and NBP decided to implement nonstandard monetary policy measures, including forward guidance, quantitative and qualitative easing. Additionally, ECB introduced negative deposit rates. In Euro Area and in USA monetary policy was also supported by fiscal packages. All these measures are a confirmation that monetary policy does not necessarily has to be doomed to a liquidity or deflation traps when policy rates are bound by zero lower floor and when economy is in depression. The nonstandard measures allowed to avoid a comeback of the Great Depression and stopped escalation of the crisis. Central banks managed to restore market's confidence and fueled liquidity into the financial market.

The size of the intervention was unprecedented and the instruments applied were nonstandard. Unfortunately, the short term successes of these measures were not 'a free lunch' and happened at the cost of decreased resilience for future possible crises. Regardless of the wide lists of possible, severe, medium and long run consequences of these actions, one thing is sure, already stretched fiscal debts and greatly expanded central banks' balance sheets create an environment extremely vulnerable to severe crisis. In case new, considerably huge contractionary shock hit again USA or Euro Area, then both fiscal and monetary policies would not be able to remain as expansionary as they were after the 2007. Moreover, improvement of central banks' balance sheets and confronting sovereign debt problems are processes, that need much time. As the economies would keep on recovering, a probability of a new crisis would gradually increase, which altogether with the imbalances in fiscal and monetary policies may prepare grounds for future severe depression. To avoid it, some rules, frameworks or exit strategies from easy monetary policy and from governments' fiscal packages are necessary.

The least resilient for the outbreak of a new crisis are USA and Euro Area. In USA public debt to GDP ratio exceeded 100 percent and the magnitude of the FED balance sheet's extension is enormous (figure 5), leaving little room for further possible expansionary policies. Euro Area seems to be more crisis-proof as the relation of debt to GDP and the percentage rise of ECB's balance sheet is considerably smaller (table 3). The safest in this matter is NBP. Despite bothered by some deflation concerns, the bank still has room for further cuts of policy rates, the relation of public debt to GDP, although alarming, is still smaller than in Euro Area and in USA, and the NBP's balance sheet percentage growth within the measured period 
is similar to the one of ECB. Nevertheless, despite implemented measures, inflation rate is still dangerously low (especially in Euro Area and in Poland).

Concluding, monetary authorities still have instruments to act in an expansionary way during ZLB, nevertheless, the case of Japan and the analysis presented in this paper show that deflation is a forceful opponent (table 2). Moreover, the more and the heavier ammunition the governments and monetary authorities use to fight deflation, the faster the bullets end (figure 5, table 3), which might possibly create a devastating liquidity trap in the future.

\section{BIBLIOGRAPHY}

Aoki M., A Desirable Inflation Targeting Policy in a Deflationary Economy: The Case of Japan, The Japan Research Institute Working Paper, http://papers. ssrn.com/ sol3/papers. cfm?abstract_id=1868633 (21.02.2015).

Bech M., Gambacorta L., Kharroubi E., Monetary policy in a downturn: Are financial crises special?, BIS Working Papers, No. 388/2012.

Chen H., Curdia V., Ferrero A., The Macroeconomic Effects Of Large-Scale Asset Purchase Programmes, „The Economic Journal”, Vol. 122, No. 564/2012, http://dx.doi.or $\mathrm{g} / 10.1111 / \mathrm{j} .1468-0297.2012 .02549$.

Christensen J.H.E., Lopez J.A., Rudebusch G.D., Extracting Deflation Probability Forecasts from Treasury Yields, „International Journal of Central Banking”, Vol. 8, No. $4 / 2012$.

Fisher I., The Debt-Deflation Theory of Great Depressions, „Econometrica”, Vol. 1, No. 4/1933, http://dx.doi.org/10.2307/1907327.

Giannone D., Lenza M., Pill H., Reichlin L., Non-Standard Monetary Policy Measures and Monetary Developments, ECB Working Paper, No 1290/2011.

Hancock D., Passmore W., Did the Federal Reserve's MBS Purchase Program Lower Mortgage Rates?, „Journal of Monetary Economics”, Vol. 58, No. 5/2011, http:// dx.doi.org/10.1016/j.jmoneco.2011.05.002.

Kumar M., Baig T., Decressin J., Faulkner-MacDonagh C., Feyzioglu T., Deflation: Determinants, Risks, and Policy Options, IMF Occasional Paper, No. 221/2003.

Kuroda H., Overcoming Deflation: The Bank of Japan's Challenge, Speech at the Council on Foreign Relations in New York, 2013.

Mishkin F.S., Westelius N.J., Inflation Band Targeting and Optimal Inflation Contracts, ,Journal of Money, Credit and Banking”, Vol. 40, No. 4/2008, http://dx.doi. org/10.1111/j.1538-4616.2008.00128.x.

Rajan R., A step in the dark: unconventional monetary policy after the crisis, Andrew Crockett Memorial Lecture by Raghuram Rajan, 2013.

Rogoff K., The Optimal Degree of Commitment to an Intermediate Monetary Target, „Quarterly Journal of Economics”, Vol. 100, No. 4/1985, http://dx.doi. org/10.2307/1885679. 
Rzońca A., Kryzys Banków Centralnych — skutki stopy procentowej bliskiej zera, C.H. Beck, Warszawa 2014.

Konstytucja Rzeczypospolitej Polskiej z dnia 2 kwietnia 1997 r. (Constitution of April 2, 1997), Dz.U., No. 78, item 483.

Ubide Á., Is the European Central Bank Failing Its Price Stability Mandate?, „Policy Brief”, Peterson Institute for International Economics, No. PB14-5/2014.

White W.R., Ultra easy monetary policy and the law of unintended consequences, „Real-world Economics Review", No. 63/2013. 
